\title{
Typification of Solanum species (Solanaceae) described by Casimiro Gómez Ortega
}

\author{
Sandra Knapp \\ Department of Botany, The Natural History Museum, Cromwell Road, London SW7 5BD, United Kingdom. s.knapp@nhm.ac.uk
}

\begin{abstract}
Knapp, S. 2013. Typification of Solanum species (Solanaceae) described by Casimiro Gómez Ortega. Anales Jard. Bot. Madrid 70(1): 56-61.

Neotypes are designated for six names coined by Casimiro Gómez Ortega that were described as members of the large genus Solanum (Solanaceae), Solanum crassifolium, S. cymosum, S. ficifolium, S. leprosum, S. subbiflorum, and S. violaceum. A brief introduction describes the role of Gómez Ortega the botany of his time, and identifies difficulties in typifying names published by him. The currently accepted name for each taxon is given. Each typification is accompanied by a discussion of the reasoning behind the choice of specimen, and all neotypes are illustrated except that of $S$. crassifolium, which has been illustrated earlier.
\end{abstract}

Keywords: typification, historic collections, exploration, garden, Linnaean, Cavanilles.

\section{INTRODUCTION}

European botanical gardens in the $18^{\text {th }}$ and $19^{\text {th }}$ centuries were the first places most botanists saw the rich wealth of the flora of the New World, either as herbarium specimens or as plants brought into cultivation from seeds sent back by early explorers. Solanaceae featured prominently in these novelties not only because the Americas are the centre of diversity at both the generic and specific ranks in the family, but also because many Solanaceae are relatively weedy and easy to cultivate. Solanum L., with ca. 1500 species, is the largest genus in the Solanaceae and one of the ten most species-rich genera of flowering plants (Frodin, 2004). As part of the collaborative project "PBI Solanum: a world-wide treatment" (see Knapp \& al., 2004; http://www.solanaceaesource.org), descriptions of all species of Solanum together with details of types and nomenclature are being provided via an on-line taxonomic resource, Solanaceae Source. One of the goals of the PBI Solanum project is to typify all Solanum names that lack precise types, helping to stabilise nomenclature and facilitate further taxonomic research. This paper is the third of a series (Knapp, 2007, 2008a,b) on the nomenclature of Solanum in which types for the names described by a particular author (rather than for a taxonomic section of Solanum) are designated.

Casimiro Gómez Ortega was the first professor of botany and director of the Real Jardín Botánico in Madrid, and in the late $18^{\text {th }}$ century had the opportunity to grow in the garden plants from the great expeditions funded by the Spanish crown. He was an early proponent of the Linnaean system of binominal nomenclature (Jarvis, 2007), but published little in the way of descriptions of new taxa. He was fiercely opposed to the use of the garden by other contemporary botanists like

\section{Resumen}

Knapp, S. 2013. Tipificación de las especies de Solanum (Solanaceae) descritas por Casimiro Gómez Ortega. Anales Jard. Bot. Madrid 70(1): 56-61 (en inglés).

Se designan los neotipos de seis nombres acuñados por Casimiro Gómez Ortega que fueron descritos dentro del género Solanum (Solanaceae), Solanum crassifolium, S. cymosum, S. ficifolium, S. leprosum, S. subbiflorum y $S$. violaceum. Se incluye una breve introducción explicando el papel de Gómez Ortega en la botánica de su tiempo, así como las dificultades que entraña tipificar los nombres publicados por él. Se incluye el nombre aceptado para cada especie. Cada tipificación se acompaña de una discusión explicando las razones para la elección de los especímenes. Todos los neotipos están ilustrados salvo el de $S$. crassifolium.

Palabras clave: tipificación, colecciones históricas, exploraciones, jardín, linneano, Cavanilles.

Antonio José Cavanilles (González Bueno, 2004), who had returned to Madrid from Paris in 1798 and whose prodigious output dwarfed his own (and who succeeded Gómez Ortega as professor and director of the garden in 1801). Cavanilles published his series of Icones et descriptiones plantarum (1791-1801), in which he described many of the plants sent by expeditionary botanists and grown in the Real Jardín Botánico, something Gómez Ortega had failed to do during his tenure as director. Gómez Ortega did, however, publish a series of descriptions of some these new plants, apparently partly in competition with Cavanilles, as Novarum, aut rariorum plantarum Horti Reg. Botan. Matrit. descriptionum decades between 1797 and 1800 (Gómez Ortega, 1797, 1798a,b, 1800). Each "decade" described between 10 and 15 species, and very few of them were illustrated, those that were appear to have been drawn from live plants. No Solanum species were illustrated in these works.

In the materials Cavanilles used to teach botany in the garden in 1802 once he became professor and director (Cavanilles, 1802), he synonymised some of Gómez Ortega's names with his that were published earlier (S. crassifolium Ortega, S. cymosum Ortega) but recognised others (e.g., S. ficifolium Ortega, S. leprosum Ortega). Still others (S. subbiflorum Ortega, S. violaceum Ortega), however, did not appear in the 1802 publication, suggesting they were no longer in cultivation in the garden and used for teaching (although see below under S. subbiflorum).

Like many botanists of the 18th century based in botanical gardens (see Jarvis, 2007), Gómez Ortega did not describe his new species from herbarium specimens, but rather from plants grown in the garden, often from seeds sent by others. This is clear from his descriptions (see below) and means that 
any types designated must be designated neotypes rather than lectotypes. In selecting the specimens I have designated as neotypes I have used the following specimen guidelines: 1) from plants cultivated at the Real Jardín Botánico in Madrid, 2) from the time Gómez Ortega was professor at the garden, 3) annotated by a staff member of the garden (often José Demetrio Rodriguez) with Ortega's epithet, and 4) good match to Ortega's protologue. Specific reasoning is described with each epithet neotypified below.

\section{TYPIFICATIONS}

Solanum crassifolium Ortega, Nov. Pl. Descr. Dec. 117. 1800, nom. superfl. illeg., non Solanum crassifolium Lam., 1794

Ind. loc.: "Habitat ... Floret in Hort. R. Matr. Mensibus Julio, Augusto, \& Septembri è seminibus communicatus a D.D. praelaudato Pourret".

Neotype, designated here: MA308535; isoneotype (fragment) F.

Current accepted name: Solanum betaceum Cav.

In her monograph of Cyphomandra (now recognised as the Pachyphyllum clade of Solanum) Bohs (1994) suggested there was no type material extant for Gómez Ortega's S. crassifolium, which is a later homonym of a name coined by Lamarck now considered a synonym of $S$. africanum Mill. (an unrelated member of the African Non-Spiny clade of Bohs, 2005). Ortega describes the seeds as coming from Pierre André Pourret (1754-1818), a French botanist who was exiled to Spain during the French Revolution (1789). I found no material in the general herbarium at MA that satisified any of my criteria; the lectotype specimen I previously chose (Knapp, 2007: 196) for $S$. betaceum is the only possible candidate too have come from plants Gómez Ortega would have seen (see Fig. 1A in Knapp, 2007). Cavanilles' description of S. betaceum (Cavanilles, 1799) is not at all similar to Ortega's, suggesting the two botanists examined the living material at different times. Although Cavanilles does not mention the source of the material it is likely that the plant both men described was originally given to the Jardín by Pierre André Pourret, who worked in Madrid for a time during his exile from France.

\section{Solanum cymosum Ortega, Nov. Pl. Descr. Dec. 12. 1797}

Ind. loc.: "Habitat in Regno Mexicanensi. Floret mense $\mathrm{Au}$ gusto, Septembri, et Octobri in Reg. Horto Matrit. è seminibus missis per $D$. Sessè".

Neotype, designated here: MA 476353.

Current accepted name: Solanum lanceolatum Cav.

I found no material in the MA general herbarium that was cultivated in the Real Jardín Botánico de Madrid filed under Solanum cymosum, nor did I find any cultivated material for S. lanceolatum, the species that best matches Ortega's protologue. The source of the seeds from which the plant described by Ortega was grown was Martin Sessé y Lacasta, the director and principal botanist of the Real Expedición Botánica a Nueva España, better known to botanists as the Sessé and Mociño Expedition. The expedition lasted sixteen years
(1787-1803), and covered territory from Guatemala to Canada, though Sessé was based in Mexico City. Full accounts of the personalities and events of the expedition can be found in McVaugh (1977), Maldonado (1997) and San Pío \& Puig Samper (2000).

A sheet in the Cavanilles herbarium (MA-476353) labelled "Solanum cimosum de Ortega" in the hand of José Demetrio Rodriguez, "Jardin de Madrid" in an unknown hand in pale brown ink and indicated as cultivated in the garden is the logical choice for a neotype (Fig. 1a); it is the only specimen I found with any connection to Ortega's epithet and that met my criteria. The sheet is of a particularly narrow-leaved plant of $S$. lanceolatum, a species described by Cavanilles two years earlier (Cavanilles, 1795), also from Mexico (but not attributed to Sessé and Mociño). The protologue does not match this specimen particularly well as it describes a plant with prickly stems and oblong leaves, but the phrase "ramea nonnulla lanceolata" suggests Gómez Ortega was specifically differentiating his plant from Cavanilles's S. lanceolatum. Solanum lanceolatum is extremely variable in leaf shape.

Solanum ficifolium Ortega, Nov. Pl. Descr. Dec. 116. 1800

Ind. loc.: "Habitat in Insula Cuba. Floret in Horto R. Matrit.

Octobri, et Novembri, è seminibus missis per D. Espinosa". Neotype, designated here: MA334586.

Current accepted name: Solanum ferrugineum Jacq.

Solanum ficifolium has long been treated as a synonym of the widespread tropical weed S. torvum Sw. (e.g., Dunal, 1813, 1852; Whalen, 1984; Nee, 1999) but none of the material in MA identifiable with Ortega's epithet corresponds to that species. It is possible that this synonymy was predicated on the type locality of Cuba cited by Gómez Ortega; seeds were said to have been sent by Mariano Espinosa, a Cuban resident and correspondent of Gómez Ortega's who was in contact with but not part of the Sessé and Mociño expedition (McVaugh, 1977; Blanco \& al., 2000). All of the material annotated as S. ficifolium I have found at MA (with a single expection see below) corresponds to $S$. ferrugineum, a species of western Mexico that does not occur on Cuba and that differs from $S$. torvum in its deflexed fruiting pedicels and glandular stellate trichomes. It is possible that Espinosa received seeds of $S$. ferrugineum from Sessé whilst the latter was in Cuba (1795-1798) and then sent them to Gómez Ortega without provenance, hence the assumption they were from a Cuban plant. Some support for this explanation can be found also in the case of Malvella leprosa (Ortega) Krapovickas (Malvaceae), a common Mexican species unknown from Cuba, that was originally described by Ortega based on plants grown from supposedly Cuban seeds sent by Espinosa (Fuertes \& Fryxell, 1993).

Four sheets annotated as S. ficifolium were found in the general herbarium at MA, all appear to have been prepared from plants grown in the garden. MA308539 bears a label "Solanum ficifolium Ortega, ex horto 1803" in the hand of José Demetrio Rodriguez and has sinuate leaves and two small inflorescences; it was collected after the publication of S. ficifolium and possibly could be from different plants to those seen by Ortega. MA334586/4 is a mixed collection with 

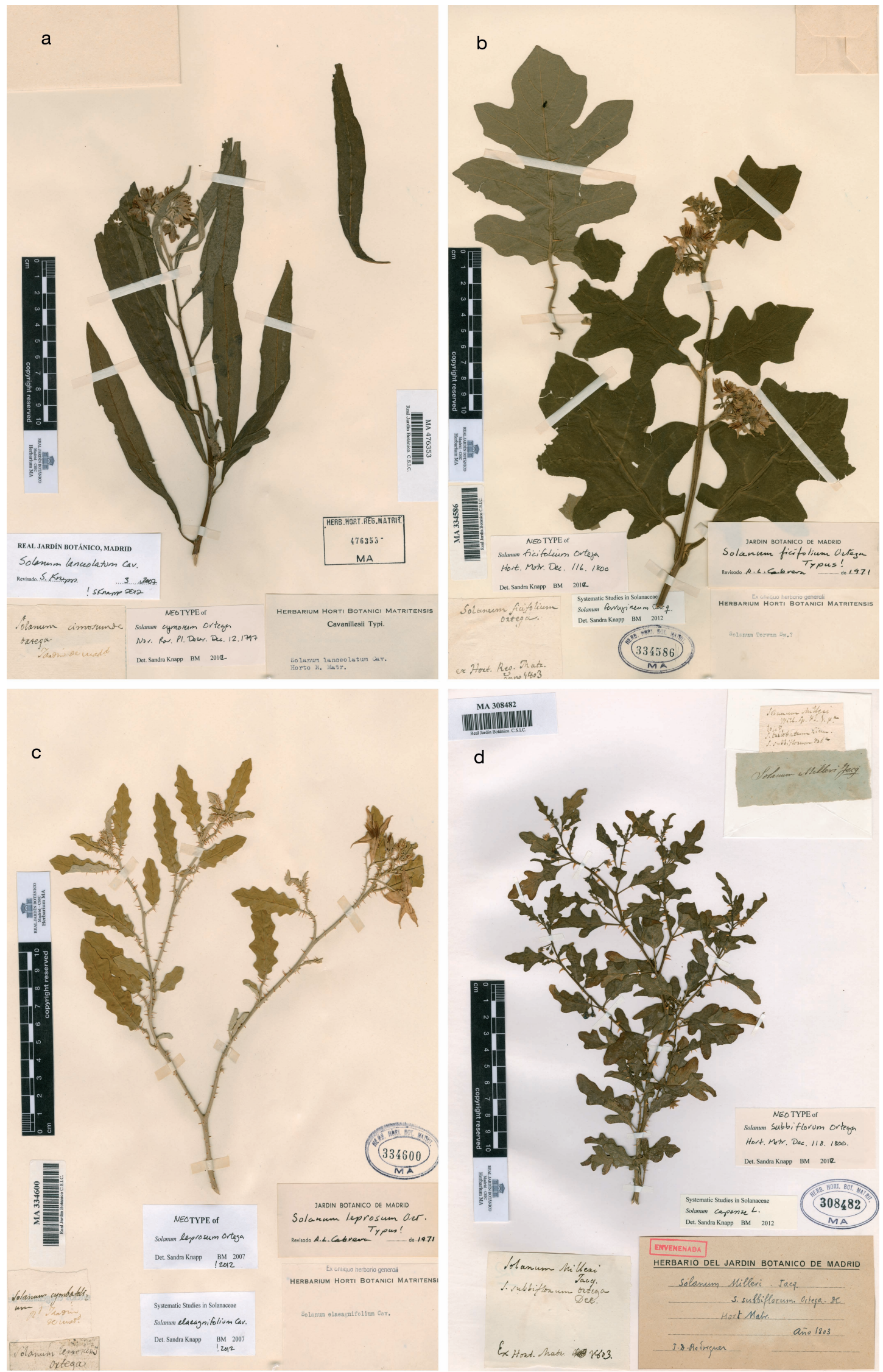

Fig. 1. a, neotype of Solanum cymosum Ortega (=Solanum lanceolatum Cav.) (MA476353); b, neotype of Solanum ficifolium Ortega (= Solanum ferrugineum Jacq.) (MA 334586); c, neotype of Solanum leprosum Ortega (=Solanum elaeagnifolium Cav.) (MA 334600); d, neotype of Solanum subbiflorum Ortega (=Solanum capense L.) (MA 308482). 
three plant fragments and two labels "Solanum ficifolium Ortega" in hand of José Demetrio Rodriguez (?) and "Solanum ficifolium [Lagasca hand]/ Ortega Decad [unknown hand]/Rl. Jardin de Madrid [pale brown unknown hand, see above]". Of the three fragments on sheet two are referable to $S$. ferrugineum Jacq., one with more or less sinuate leaves (in the upper $\mathrm{L}$ of the sheet) and the other with the characteristic deflexed fruiting pedicels of that species (lower right of the sheet); neither of these fragments have flowers. The third plant fragment is a tiny piece of what appears to be S. capense L. A sheet (MA334586/2) labelled "Solanum ficifolium Ortega" in unknown hand consists of three fragments that are clearly referable to $S$. ferrugineum, two have flowers and fruit on deflexed pedicels and the third only flowers. These fragments are from older plants with angular (not sinuate) leaves, in Solanum juvenile leaves are often repand and sinuate (Roe, 1966). Also filed as S. ficifolium MA334586/3 has a typed label stating "ex. Hort Matr 1803" and is a good specimen of $S$. ferrugineum.

MA334586 was annotated as "lectotype" by A.L. Cabrera 1971 but the lectotypification was never published. This specimen (Fig. 1B) has a label with "Solanum ficifolium Ortega/ ex Hort. Reg. Matr. anno 1803" in hand of José Demetrio Rodriguez and is a young flowering plant with sinuate leaves and three inflorescences (one of which is branched). This sheet best matches Ortega's protologue which mentions both sinuate leaves and branched inflorescences and so is here selected as the neotype (Fig. 1b). Although this juvenile plant lacks the diagnostic fruiting pedicels, the stems and inflorescences have the glandular stellate trichomes characteristic of $S$. ferrugineum.

Solanum leprosum Ortega, Nov. Pl. Descr. Dec. 115. 1800

Ind. loc.: "Habitat in Regno Chilensi. Floret in Horto R. Matrit. Septembri et Octobri è seminibus missis per D. Nee”. Neotype, designated here: MA334600; possible isotypes MA 334600/2, MA334600/3.

Current accepted name: Solanum elaeagnifolium Cav.

I found several sheets filed as $S$. leprosum in MA (MA 334600, MA334584, MA3334600/2, MA334600/3); of these only MA 334600 (the 3 sheets) are potential neotype material, as MA334584 does not match the protologue in being from Mexico ("Nee iter, Nueva Espana") and being non-prickly version (prickles are mentioned in the protologue). The three sheets of MA 334600 are probably from the same plant; their morphology is all very similar. All are labelled as S. leprosum Ortega; MA334600/2 with "Solanum leprosum Ortega, Ex. Hort. Matri. 1800" in the hand of José Demetrio Rodriguez, MA334600/3 as "Solanum leprosum Ortega decade/" in an unknown hand, and MA334600 as "Solanum leprosum Ortega" in what is probably the hand of Rodriguez, but without a date. MA334600 is the best preserved sheet and has a bud and two flowers clearly showing the declinate style mentioned in the protologue and is chosen here as the neotype (Fig. 1c). All of these specimens are clearly identifiable as S. elaeagnifolium, described by Cavanilles five years earlier, also from material collected in Chile by Luis Née, the botanist on the Malaspina Expedition (1789-1794; Muñoz Garmendia, 1992) that circumnavigated the globe and sent many novelties back to Spain for cultivation in the Jardín Botánico.

\section{Solanum subbiflorum Ortega, Nov. Pl. Descr. Dec. 118. 1800}

Ind. loc.: "La planta se cultiva en el jardín de esta Corte... Lo he visto en flor y fruto en dicho jardín".

Neotype, designated here: MA308482.

Current accepted name: Solanum capense L.

No material filed as S. subbiflorum was found in the general herbarium, in the list of plants used by Cavanilles in teaching in the year 1801 (Cavanilles, 1802) S. subbiflorum was recognised as a synonym of Solanum milleri Jacq. (itself a synonym of $S$. capense L.).

Filed as Solanum milleri in the general herbarium are several sheets, two were not collected from plants cultivated "en el jardín de esta Corte"; MA573873 is a specimen donated by a secondary school in San Isidro and MA 308506 was collected on an unknown date by a Sr. Pascal. Two additional sheets are from material cultivated at the Real Jardín Botánico; one is too late to have been collected from the same plant Gómez Ortega used for his description (MA3084902, dated 1844). MA 308482 (Fig. 1d) is annotated as "Solanum milleri Jacq./Solanum subbiflorum Ortega/ Ex Hort. Matr. 1803" in the hand of José Demetrio Rodriguez and is likely to be material from the same plants used by Gómez Ortega three years earlier to describe $S$. subbiflorum and I have selected this sheet as the neotype. All of these sheets are identifiable as S. capense $\mathrm{L}$.

\section{Solanum violaceum Ortega, Nov. Pl. Descr. Dec. 56. 1798}

Ind. loc.: "Habitat en Bahia Botanica. Floret Octobri et Novembri in Reg. Hort. Matrit. è seminibus Londino missis per Exc. D. Marchionissam de Bute".

Neotype, designated here: MA307449; possible isotype MA 208082.

Current accepted name: Solanum violaceum Ortega.

Solanum violaceum is the currently accepted name for the species long known as $S$. indicum $\mathrm{L}$. That name appears in Appendix II of the Code (McNeill \& al., 2006) and was rejected based on inconsistency of its use and the confusion created by this (see Hepper, 1978). Solanum violaceum is a wide spread weedy species occurring throughout Asia and into the Mascarene Islands of the Indian Ocean; Hepper (1978a) quite incorrectly synonymised it with $S$. anguivi $\mathrm{Lam}$., a very similar but different widespread species of Africa (see Vorontsova \& Knapp, 2012).

Two specimens in MA, both from plants cultivated in the Real Jardín Botánico ("Hort. Reg. Matr."), are identifiable as S. violaceum. One is a poor sheet with crumpled unusually small leaves and fruits only (MA208082, Kew negative 17003 taken in Jan 1977), is labelled "Rl. Jard de Mad" in the unknown pale brown hand (see above) and bears no date; the other (MA 307449) is in flower and fruit and has a label "Solanum indicum Linn./Solanum violaceum Ortega/ Hort. Reg. Matr./año 1801" in hand of José Demetrio Rodriguez. The late Richard N. Lester in appropriately annotated the fruiting specimen as "holotype" material. This sheet does not 


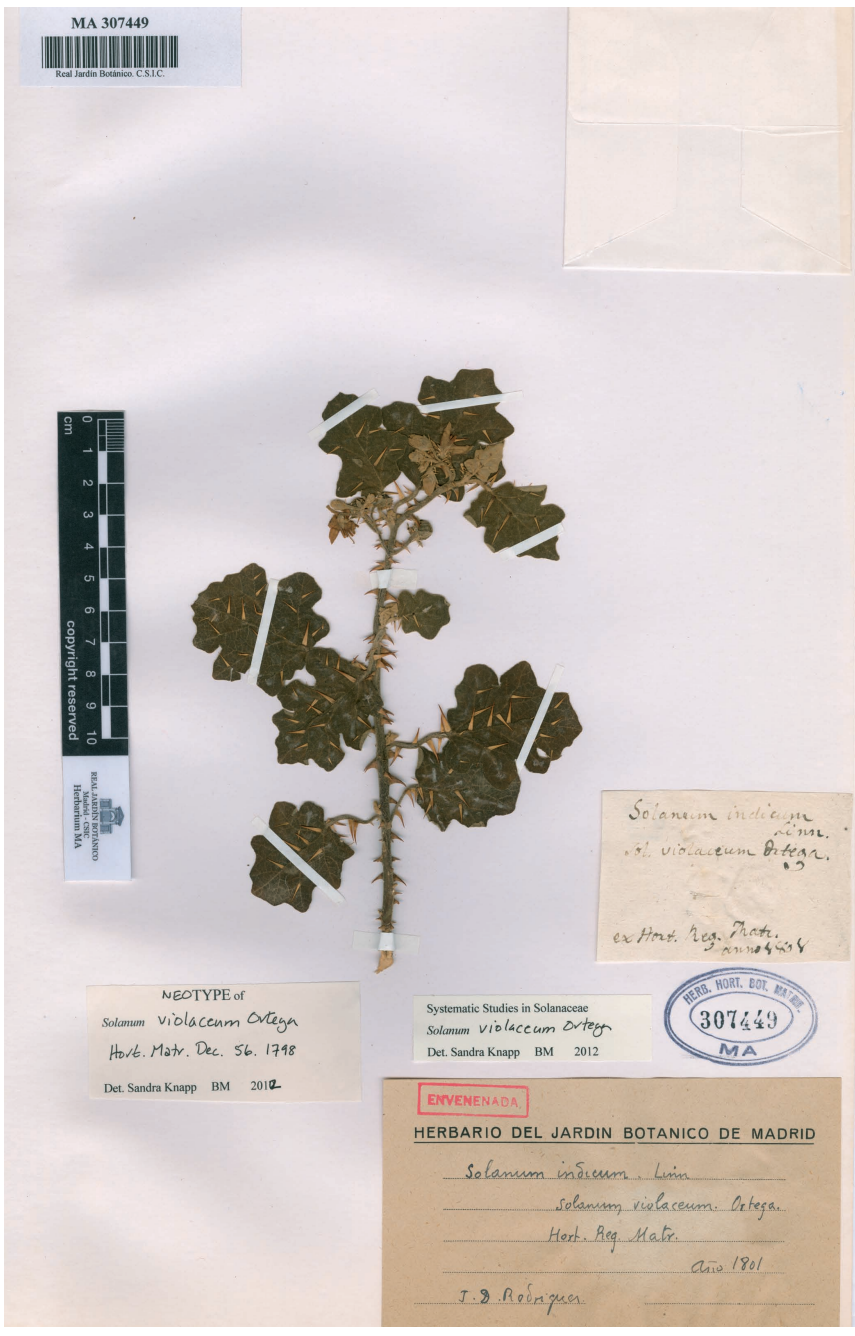

Fig. 2. Neotype of Solanum violaceum Ortega (MA 307449)

correspond to the protologue, and in addition to being a poor specimen does not have the long straight fruiting pedicels of material currently identified as $S$. violaceum. The flowering sheet (MA307449, Fig. 2) corresponds better to the protologue description of sinuate leaves "cordatis sinuatis" with cordate bases, has a date consistent with it being cultivated when Gómez Ortega's tenure as director and is thus the logical choice for a neotype. Although the sheet is dated 1801, this species does not appear in Cavanilles's (1802) teaching list.

The protologue states seeds were originally collected "Bahia Botanica" (Botany Bay in New South Wales, Australia) and were obtained from the Marquess of Bute, John Stuart the $4^{\text {th }}$ Earl of Bute who, like Gómez Ortega, was a Fellow of Royal Society in London. The seeds from which these plants were grown were possibly brought back by Joseph Banks, another member of the Royal Society and friend of Bute. There are no herbarium specimens of $S$. violaceum definitely attributable to Banks in BM, but a sheet of a plant grown in the Chelsea Physic Garden in London (BM000942956) is dated 1778. I suspect the seeds received by Gómez Ortega were from the same source as this Chelsea plant, most likely India; $S$. violaceum does not occur in Australia.

\section{ACKNOWLEDGMENTS}

Thanks are due to the late Prof. S. Castroviejo and the staff of the Real Jardín Botánico de Madrid for hospitality during my stay in Madrid in 2008, and to Prof. F. Muñoz Garmendia for imparting his knowledge of the history of Spanish botany to me in subsequent visits; I learned so much, and realised I knew so little, about the history of botany in Spain; photographs of the neotypes were taken by staff of the RJB; my stay in Madrid in 2008 was funded from the SYNTHESYS Project http://www.synthesys.info/ which is financed by European Community Research Infrastructure Action under the FP6 "Structuring the European Research Area" Programme and the National Science Foundation Planetary Biodiversity Inventory (award DEB-0316614 'PBI Solanum - a worldwide treatment' - http:nhm.ac.uk/ solanaceaesource).

\section{REFERENCES}

Blanco, P., M.A. Puig-Samper, G. Zamudio, M. Valero \& J.L. Maldonado. 2000. Exploración botánica de las Islas de Barlovento: Cuba y Puerto Rico. Siglo XVIII. La obra de Martín de Sessé y José Estévez. Ediciones Doce Calles-CSIC, Aranjuez.

Bohs, L. 1994. Cyphomandra (Solanaceae). Flora Neotropica 63:1-175.

Bohs, L. 2005 Major clades in Solanum based on $n d b F$ sequences, pp. 27-49. In: Keating, R.C., Hollowell, V.C. \& Croat, T.B. (eds.), A festschrift for William G. D'Arcy: the legacy of a taxonomist. Monographs in Systematic Botany from the Missouri Botanical Garden, Vol. 104. Missouri Botanical Garden Press, St. Louis.

Cavanilles, A.J. 1795. Icones et descriptiones plantarum. Volumen 3(1). Lazaro Gayguer, Madrid.

Cavanilles, A.J. 1799. Descripcion de cinco géneros nuevos y otras plantas. Anales de Historia Natural 1: 33-45.

Cavanilles, A.J. 1802. Descripción de las plantas que D. Antonio Josef Cavanilles demostró en las lecciones publicas del año 1801. Imprenta Real, Madrid.

Dunal, M.-F. 1813. Histoire naturelle, médicale et économique des Solanum et des genres qui ont été confundus avec eux. Montpellier.

Dunal, M.-F. 1852. Solanaceae, pp. 1-690. In: A.P. de Candolle (ed.), Prodromus systematis naturalis regni vegetabilis $13(1)$. V. Masson, Paris.

Frodin, D.G. 2004. History and concepts of big plant genera. Taxon 53: 753 776.

Fuertes J.\& P.A. Fryxell 1993. Types of names of New World Malvaceae of Lagasca, Ortega, and Sessé \& Mociño. Taxon 42: 345-354

Gómez Ortega, C. 1797. Novarum, aut rariorum plantarum Horti Reg. Botan. Matrit. descriptionum decades [Decas prima, secunda, tertia, et quarta]. Ibarra, Madrid.

Gómez Ortega, C. 1798a. Novarum, aut rariorum plantarum Horti Reg. Botan. Matrit. descriptionum decades[Decas quinta, et sexta]. Ibarra, Madrid.

Gómez Ortega, C. 1798b. Novarum, aut rariorum plantarum Horti Reg. Botan. Matrit. descriptionum decades [Decas septima, et octava]. Ibarra, Madrid.

Gómez Ortega, C. 1800. Novarum, aut rariorum plantarum Horti Reg. Botan. Matrit. descriptionum decades [Decas nonas, et decima]. Ibarra, Madrid.

González Bueno, A. 2004. Antonio José Cavanilles (1745-1804), el botánico de la Ilustración, pp. 52-89. In: Muñoz Garmendia, F. (ed.), La botánica Ilustrada Antonio José Cavanilles (1745-1804), jardines, botánicos y expediciones cientificas. CSIC, Lunwerg Editores, Madrid.

Hepper, F.N. 1978. Typification and name changes of some Old World Solanum species. Botanical Journal for the Linnean Society 76: 287-292.

Jarvis, C. 2007. Order out of chaos: Linnaean plant names and their types. Linnean Society of London and the Natural History Museum, London.

Knapp, S. 2007. Lectotypification of Cavanilles' names in Solanum (Solanaceae). Anales del Jardín Botánico de Madrid 64: 195-203.

Knapp, S. 2008a. Typification of Solanum (Solanaceae) species described by Martin de Sessé y Lacasta and José Mariano Mociño. Anales del Jardín Botánico de Madrid 65: 7-23.

Knapp, S. 2008b. Lectotypification of Ruiz and Pavón's names in Solanum (Solanaceae). Anales del Jardín Botánico de Madrid 65:307-329.

Knapp, S., L. Bohs, M. Nee \& D.M. Spooner. 2004. Solanaceae: a model for linking genomics and biodiversity. Comp. Funct. Genomics 5: 285-291.

Maldonado, J.L. \& M.A. Puig-Samper. 2000. La aventura ultramarina de Sessé y Mociño, la Real Expedición Botánica a Nueva España. Pp. 36-52. In: De San Pío Aladrén, M.P. \& M.A. Puig-Samper (eds.), El águila y el 
nopal: la expedición de Sessé y Mociño a Nueva España (1787-1803). Lunwerg Editores S.A., Barcelona.

McVaugh, R. 1977. Botanical results of the Sessé and Mociño expedition (1787-1803) I. Summary of excursions and travels. Contributions from the University of Michigan Herbarium 11: 97-195.

Muñoz Garmendia, F. 1992. La expedición Malaspina 1789-1794. Tomo III. Diarios y trabajos botánicos de Luis Née. Ministerio de Defensa, Madrid.

Nee, M. 1999. Synopsis of Solanum in the New World, pp. 285-333. In: Nee, M., D.E. Symon, R.N. Lester \& J.P. Jessop (eds.), Solanaceae IV. Royal Botanic Gardens, Kew, Richmond.

Roe, K.E. 1966. Juvenile forms in Solanum mitlense and S. blodgettii (Solanaceae) and their importance in taxonomy. Sida 2(5): 381-385.

San Pío Aladrén, M.P. de \& M.A. Puig-Samper (eds.). 2000. El águila y el nopal: la expedición de Sessé y Mociño a Nueva España (1787-1803). Lunwerg Editores S.A., Barcelona.

Vorontsova, M.S. \& S. Knapp. 2012. Solanum sections Oliganthes, Melonge$n a$ and Monodolichopus. Pp. 164-186, 198-215, 220-223, Edmonds, J.M., Solanaceae. In: H. Beentje (ed.), Flora of Tropical East Africa. Royal Botanic Gardens, Kew, Richmond.

Whalen, M.D. 1984. Conspectus of species groups in Solanum subgenus Leptostemonum. Gentes Herbarum 12: 179-282.

Associate Editor: Javier Fuertes Received: 21-XI-2012 Accepted: 26-IV-2013 